\title{
Performance of sex sorted semen under Indian Small Holder Dairy Farming Systems
}

\author{
Sachin Joshi*, Kaustubh Bhave, Vinod Potdar, Yuvraj Gaundare, \\ Nikhil Punde, Tejashree Shirsath and Marimuthu Swaminathan
}

Central Research Station, BAIF Development Research Foundation, India

*Corresponding author

\section{A B S T R A C T}

\section{Keywords}

Dairy farming systems,

Sex sorted semen

Article Info

\section{Accepted:}

10 January 2021

Available Online:

10 February 2021
The objective of the study was to evaluate the performance of sex sorted semen that was produced for the first time in India at BAIF semen production facility, Pune, using the technological processes of sexing technologies, USA, under tropical small holder dairy production systems. Additionally, a notable point is that the semen was produced from the population of Indian breeds of cattle, its crosses and buffaloes which co-evolved and adopted to the country' agro climatic conditions. 21,012 artificial insemination data and 2,284 calving records were included in the analysis. The parameters evaluated were conception rate and sex ratio. The statistical analysis was performed using the logistic regression method to estimate the effect of factors on conception rate. The effects studied were states, order of lactation, month of insemination, and breed of bull. The overall mean conception rate was $39.92 \pm 0.5$ per cent, while the sex ratio of female to male was found to be $90.9 \%$. All of the effects included in the study significantly influenced the conception rate. Odisha state reported higher conception rate while low conception rate was found in Uttarakhand state. Conception rate increased gradually from November to April and declined later. Heifers showed higher conception rate than cows with subsequent lactations, however the difference among the other lactations was very less. The Holstein Friesian crossbred bulls with 75 per cent exotic blood level showed better conception rate than the rest of the breeds. Present study highlights the technical performance and merits of using sex sorted semen in the Indian dairy sector as a way to increase the country' milk production and reduce the burden of maintaining male calves at farm level.

\section{Introduction}

Globally, the use of artificial insemination (A.I.) technique is considered as a boon to dairy industry. The AI technique besides helping the farmers to improve the genetics of their dairy herds, also boosting the farm' milk production and the farmers' income. This could be witnessed bythe quantum jump in India' milk production between 2017-18 and 2018-19. The milk production increased from 176.3 million tons to 187.7 million tons during this period with an annual growth rate of $6.47 \%$. (GoI, 2019) could be a testimonial to the claim of increased milk production at the farm levels. Despite the growth in the 
dairy sector, the dairy farmers are faced with different farm level challenges such as production of male calves that has no value in the increasingly specialized dairy system, Further, there are calving difficulties arising out of heavy male calf births, availability of replacement heifers in herd, anti-slaughter acts in cattle, growing feed and fodder deficits, etc., that are hindering the progress of dairy industry. Female sex sorted semen could provide a way out in meeting the above challenges.The available biotechnological tools like sperm mediated gene transfer (Niemann et al., 2011), embryo biopsy etc. to select desired sex of calf before birth are expensive and time consuming.

The evolution of sperm sorting technique in the breeding industry provides the opportunity for selection of potentially superior females, better replacement rate by producing more heifers (Hohenboken, 1999; Weigel, 2004; Moce et al., 2006). It not only increases the genetic gain but also reduces the cost of progeny testing (De Vries et al., 2008). Apart from these merits, with anti-cow slaughter law in place, the farmer could get rid of unnecessary male calves born due to conventional semen.

Sex Sorted Semen technique had given promising results in the past in different countries such as sex sorted semen performance of Holsteins in United states (Norman et al., 2010) and (DeJarnette et al., 2008) Holstein heifers in Australia (Healy et $a l .$, 2013). But there are no published reports on the performance of sex sorted semen under Indian field condition.

The present study therefore addresses the technical efficiency on the use of sex sorted semen produced under Indian conditions using the breeds of Indian cattle and buffaloes, and tested under the different production environments across the selected states of India.

\section{Materials and Methods}

\section{Area of study}

The present study was conducted in 940 field Artificial Insemination (AI) centers of BAIF Development Research Foundation located in 147 districts of 7 states (Uttarakhand, Uttar Pradesh, Rajasthan, Madhya Pradesh, Gujarat, Maharashtra, and Odisha). BAIF Development Research Foundation (BAIF Development Research Foundation 2020), a large NGO located close to Uruli Kanchan near Pune, providing door-to-door cattle and buffalo AI service to about 5 million families of small farmers in over 100,000 villages in 13 states.

A total of 21,012 inseminations were carried out in 19,178 cows of various genetic makeup belonging to 16,405 farmers. The inseminations were carried out over a period of 2 years, between December 2018 and December 2020. A total of 2,284 calving were followed which included abortion, still birth, dystocia and normal calving. All the cows inseminated with sex sorted semen were tagged with 12-digit unique identity number and the data pertaining to inseminations were collected through an online digital platform, stored and analyzed using BAIF' data storage and data management pipeline.

\section{Processing of sex sorted semen}

The BAIF frozen semen station and the semen sex sorting facility is located in Maharashtra state, India, in the outskirts of Pune city $\left(18.5^{\circ} \mathrm{N}\right.$ latitude $\left.73.8^{\circ} \mathrm{E}\right)$ and at an altitude of $559 \mathrm{~m}$ above sea level. sex sorted semen is being produced at BAIF frozen semen station using Sex ULTRA $^{\mathrm{TM}}$ sperm sex sorting technology, a patented technology of Sexing Technologies (ST), USA. Sexing Technologies (ST) is the pioneer in the field of sex sorting technology in the World. The 
bovine semen sex sorting techniques were originally invented by ST's subsidiary XY, LLC and licensed to ST. The semen sorting and the processing was done as per the method explained by Gonzalez-Marín et al., (2018). Every single batch of sex sorted semen was subjected for quality control using standard protocols.

The quality standards of the sex sorted frozen semen used in the study as per the prescribed norms were: gender purity, as assessed during the laboratory process was greater than 90 per cent; Post thaw incubation of progressive motility at 0 and 3 hours were above 50 and 30 per cent, respectively; Bacterial count was below $100 \mathrm{CFU}$; The final concentration of spermatozoa was minimum 2.1 million sperms per frozen semen straw

\section{Parameters studied and influencing factors}

The parameter studied were conception rate (coded as 0: not conceived and 1: conceived) and sex ratio of sex sorted semen. Conception rate $(\mathrm{CR})$ was estimated as the proportion of pregnancies confirmed by the rectal palpation of the genital tract at 90 to 120 days of postinsemination, against the total number of inseminations followed for pregnancy diagnosis, over a period of time. Different factors included in the analysis were states, month of insemination, body condition score, order of parity, breed of cow, and breed of bull in order to determine their effect on the conception rates. Seven states viz., Uttarakhand, Uttar Pradesh, Rajasthan, Madhya Pradesh, Gujarat, Maharashtra, and Odisha were included as a separate class. Seasonal variation was captured by month of inseminations as a separate class. Order of lactation was group in heifer, first to fifth lactation and more than 6 lactations. Body condition score were categorized as 1 to 5 on the basis of visible ribs (All ribs exposed: 1, three ribs exposed: 2 , two ribs exposed: 3 , one rib exposed: 4, and no rib exposed: 5). Cow breed was divided briefly in 3 groups: recognized indigenous cattle breed, Holstein Friesian and Jersey crossbreed and nodescript cattle breed. Breeds of bulls included were pure Holstein Friesian and Jersey, crossbred of Holstein Friesian and Jersey of 50 and 75 per cent exotic inheritance, Gir, Sahiwal, Red Sindhi and Tharparkar.

\section{Data processing and statistical analysis}

The artificial insemination data was trimmed in order to remove outliers. District with less than 100 inseminations were excluded. Bulls with less than 30 inseminations were removed from the analysis. The most commonly used multiple regression analysis technique poses difficulty when the dependent variable has only two outcomes viz. event occurring or not occurring. In such a data-set the assumption of normal distribution and equality of variances are violated. Conception rate follows the binary data structure having only one of the two possibilities namely, success or failure. To handle such binary data structure, logistic regression model is found to be a better choice (Dyke and Patterson, 1952; Ron et al., 1984, Hosmer and Lemeshow, 1989) and hence adopted in the present studies. To investigate the differences in conception rate between different sub classes of independent variables, a binary logistic regression model was constructed with conception rate as the dependent variable and different independent variables of interest along with an interaction effect was included. It was observed that body condition score and breed of cow were found non-significant, hence removed from the analysis.

The interaction of state $\times$ month of insemination found to be significant, and therefore included in the analysis. All the procedure of data cleaning and statistical analysis was performed using $\mathrm{R}$ statistical software (R Core Team, 2020). 


\section{Results and Discussion}

The overall conception rate of sex sorted semen was $39.92 \pm 0.5$ per cent. The sex ratio of female to male was found to be 90.98 .

\section{Conception rate}

Healy (2013) found that the empirical conception rates were $31.6 \%$ for sexed semen and $39.6 \%$ for conventional semen. S.B. Patel and P.C. Jethva (2019) got $39.53 \%$ conception rate of sexed semen in their study which is equal compared to our findings. While Djedovic et al., (2016) observed a conception rate of $44 \%$. The factors that had a very high significant effect $(\mathrm{P}<0.001)$ on the conception rate were: Sex-sorting, heifer age at breeding, THI (Temperature-Humidity Index), AI technician, service number, and insemination sire. The present study is in accordance with the earlier studies where by DeJarnette et al., (2011) found a conception rate between $38 \%$ and $44 \%$. Norman et al., (2010) reported mean conception rate for heifers as $39 \%$ for sexed semen. Seidel \& Schenk (2002) also reported similar conception rate ranging from 31 to $42 \%$ for sexed semen I. Cerchiaro et al., (2007) reported a conception rate range between 43.1 and 59.0 for sex sorted semen.

\section{Factors influencing conception rate}

The effect of different factors influencing conception rate of sex sorted semen is presented in Table 1.

The conception rate of sex sorted semen was significantly $(\mathrm{p}<0.01)$ different among the inseminations carried out in seven different states. For the state variable, Gujarat state was considered as reference class. The probability of getting a cow pregnant was high in Odisha states while lowest in Uttarakhand state. The difference among the Uttar Pradesh, Madhya
Pradesh and Maharashtra were very small. The difference among the states was attributed to the different agro climatic condition and likelihood variation in the characteristics in locally adopted strains of cows.

Month of insemination significantly influenced $(p<0.05)$ the conception rate of sex sorted semen. The April month was considered as a reference value and other month class was compared with it. The estimated means of conception rate ranged between 0.36 (October) to 0.47 (April). It was observed that the conception rate increased from November and reached to peak by April and gradually reduced till October. The reason for the increasing trend of conception rate could be due to availability of fodder resources and weather condition until March to April. The interaction between states and month of insemination (Figure.1) showed similar pattern in Maharashtra and Uttarakhand which declined drastically after April. Conception rate in Uttar Pradesh and Gujarat declined steadily from March and continues to do so until September to October. Although there exists a within state agro-eco system and climatic variation, for the management reasons, the state is considered as one composite agro-climatic zone in this study. It is possible to disentangle those within state variations with additional data.

Order of lactation had significantly influenced $(\mathrm{p}<0.05)$ the conception rate of sex sorted semen. Heifer class was regarded as reference variable. The probability of pregnancy was highest in heifer and declined slowly with parity. The difference among the remaining lactations was not significant. The decrease of conception rates of older lactating cows was likely due to inability to maintain normal body temperature because of high rate of internal heat production associated with 
lactation. Conversely, non-lactating heifers are more likely to have a greater range of environmental temperature within which fertility is not impaired (Badinga et al., 1985). Apart from this, Gwazdauskas et al., (1981) and Fonseca et al., (1983) reported age wise decline in conception rate in dairy cattle. Reduced conception rate in older animals could be due to subsequent problems associated with multiple calving and reproductive problems faced during early post-partum period.
The breed of bull had very high significant ( $\mathrm{p}$ $<0.01$ ) on conception rate of sex sorted semen in the field. Gir breed was regarded as the reference class. The probability of pregnancy was higher in Holstein Friesian crossbred bulls with the exotic inheritance of 75 per cent followed by Tharparkar, Sahiwal and Jersey crossbred with 50 per cent exotic inheritance. The lowest probability of success observed in the Red Sindhi bulls with lowest odds ratio (0.82).

Table.1 Class of variables, number of inseminations, raw conception rate, odds ratio, probability and estimated conception rate in cows conceived by sex sorted semen

\begin{tabular}{|c|c|c|c|c|c|}
\hline Class variable & $\begin{array}{c}\text { Number of } \\
\text { inseminations }\end{array}$ & $\begin{array}{c}\text { Raw } \\
\text { mean CR }\end{array}$ & $\begin{array}{l}\text { Odds } \\
\text { ratio }\end{array}$ & ${ }^{1}$ Probability & $\begin{array}{c}{ }^{2} \text { Estimated } \\
\text { CR }\end{array}$ \\
\hline \multicolumn{6}{|c|}{ States** } \\
\hline Uttar Pradesh & 7064 & 0.41 & 1.17 & 0.54 & 0.40 \\
\hline Maharashtra & 4004 & 0.43 & 1.12 & 0.53 & 0.39 \\
\hline Gujarat $\dagger$ & 3221 & 0.37 & 1 & 0.5 & 0.37 \\
\hline Odisha & 2860 & 0.47 & 1.54 & 0.61 & 0.45 \\
\hline $\begin{array}{l}\text { Madhya } \\
\text { Pradesh }\end{array}$ & 741 & 0.41 & 1.17 & 0.54 & 0.39 \\
\hline Rajasthan & 517 & 0.34 & 0.87 & 0.47 & 0.35 \\
\hline Uttarakhand & 2605 & 0.29 & 0.72 & 0.42 & 0.31 \\
\hline \multicolumn{6}{|c|}{ Order of Lactation* } \\
\hline Heifer $\uparrow$ & 4355 & 0.43 & 1 & 0.5 & 0.43 \\
\hline 1 & 3810 & 0.4 & 0.89 & 0.47 & 0.40 \\
\hline 2 & 5453 & 0.39 & 0.89 & 0.47 & 0.40 \\
\hline 3 & 4415 & 0.39 & 0.9 & 0.47 & 0.40 \\
\hline 4 & 1882 & 0.38 & 0.87 & 0.47 & 0.41 \\
\hline 5 & 656 & 0.38 & 0.85 & 0.46 & 0.39 \\
\hline 6 and above & 441 & 0.4 & 0.96 & 0.49 & 0.42 \\
\hline \multicolumn{6}{|c|}{ Month of Inseminations* } \\
\hline January & 2413 & 0.41 & 0.81 & 0.45 & 0.42 \\
\hline February & 2360 & 0.43 & 0.86 & 0.46 & 0.43 \\
\hline March & 1666 & 0.44 & 0.97 & 0.49 & 0.46 \\
\hline April & 900 & 0.47 & 1 & 0.5 & 0.47 \\
\hline May & 1415 & 0.45 & 0.91 & 0.48 & 0.45 \\
\hline June & 1593 & 0.4 & 0.79 & 0.44 & 0.41 \\
\hline July & 2035 & 0.39 & 0.78 & 0.44 & 0.41 \\
\hline August & 1859 & 0.38 & 0.72 & 0.42 & 0.39 \\
\hline
\end{tabular}




\begin{tabular}{|l|c|c|c|c|c|}
\hline September & 1705 & 0.36 & 0.66 & 0.4 & 0.37 \\
\hline October & 1457 & 0.35 & 0.65 & 0.39 & 0.36 \\
\hline November & 1624 & 0.36 & 0.66 & 0.4 & 0.37 \\
\hline December & 1985 & 0.38 & 0.72 & 0.42 & 0.39 \\
\hline Breed of Bull** & \multicolumn{5}{|l|}{} \\
\hline HF 100\% & 2382 & 0.35 & 0.94 & 0.48 & 0.36 \\
\hline HF 50\% & 942 & 0.39 & 1.15 & 0.54 & 0.39 \\
\hline HF 75\% & 2429 & 0.46 & 1.32 & 0.57 & 0.42 \\
\hline JR 100\% & 3243 & 0.41 & 1.01 & 0.5 & 0.37 \\
\hline JR 50\% & 191 & 0.48 & 1.18 & 0.54 & 0.45 \\
\hline JR 75\% & 1094 & 0.4 & 0.92 & 0.48 & 0.35 \\
\hline Gir† & 5391 & 0.37 & 1 & 0.5 & 0.37 \\
\hline Sahiwal & 4365 & 0.41 & 1.18 & 0.54 & 0.40 \\
\hline Tharparkar & 758 & 0.43 & 1.2 & 0.54 & 0.41 \\
\hline Red Sindhi & 217 & 0.42 & 0.82 & 0.45 & 0.33 \\
\hline
\end{tabular}

Significance codes: ‘**’: $p<0.01,{ }^{\prime *}: \mathrm{p}<0.05$. : Reference class of variable. ${ }^{1}$ The figure of 0.5 under relative probability indicates the reference figure for comparison with others as chosen by the Logit Regression Analysis method. The figures are odd ratio of Success (or Failure)/ Number of events, viz. Conceived (or Not Conceived)/ Number of AI. ${ }^{2}$ Estimated conception rates are computed after substituting actual figure (LS mean) in place of First reference values, converting the rest of the odds ratios accordingly

Fig.1 Effect of interaction of state and month of insemination on conception rate

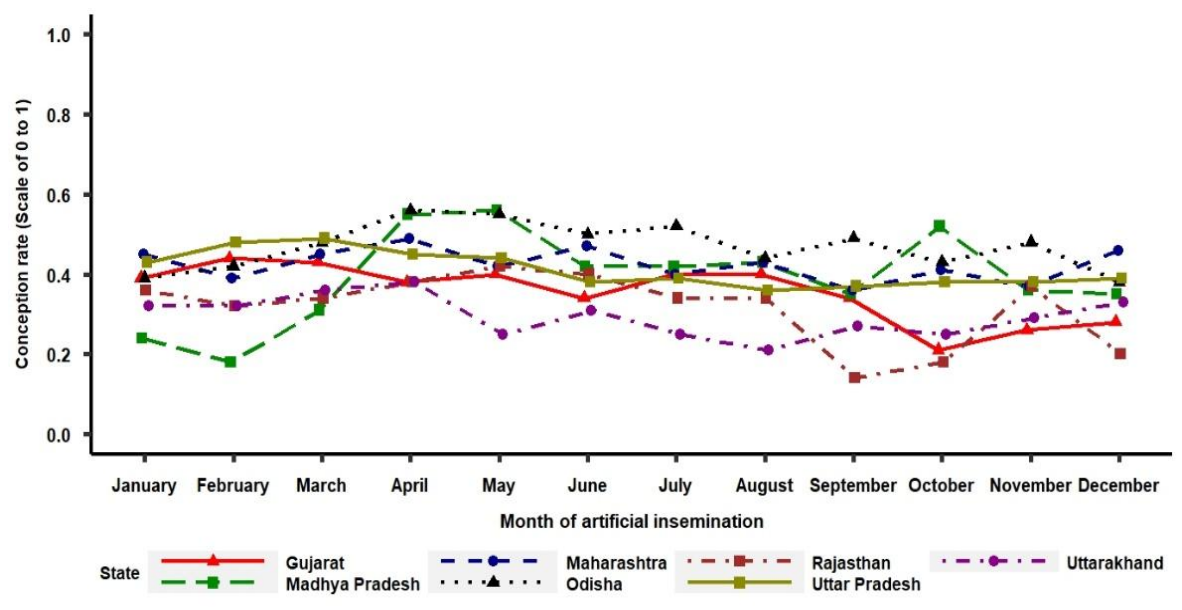

\section{Calving and female sex ratio}

In respect of the reported female sex proportion in our study $(90.9 \%)$, Patel and Jethva (2019) in their study reported that out of 68 pregnant heifers, 2 heifers aborted and one heifer died before calving. Out of 65 animals that calved, 54 heifers delivered live female calves, 9 heifers had male calves, and two had female stillbirth. Thus, with regards to sex of calf born with sexed semen including stillbirths, $86.15 \%$ were female calves and $13.85 \%$ were male calves. In another study at three centers of Lohaghat block of Uttarakhand state, India, 70 cows were inseminated with sexed semen, and the conception rate, female calves and male calves born were $40.00 \%, 82.14 \%$ and $17.85 \%$, respectively (Sharma et al., 2018). Cerchiaro et al., (2007) reported percentage 
of female calves ranges from 75 to 90.7 out of 258 cow's calving for sexed sperm.

\section{Calving difficulties}

A total of 2,284 calvings were followed out of which, 47 abortion (2.05 per cent), 37 still births (1.61 per cent), 3 dystocia ( 0.13 per cent) and 2196 cows had normal calving (96.18 per cent). The higher percentage of female calves led to reduced dystocia for both heifers and cows, especially for twin births. Stillbirths were less frequent for twins when sexed semen was used. An increase in stillbirth rate for heifers was observed for single calves, especially males, with sexed semen use (Norman et al., 2010).

The abortion rates for sexed and conventional semen were similar. This is in agreement with other studies that report identical stillbirth and abortion rates for sexed and conventional semen (Tubman et al., 2004; Seidel, 2007; DeJarnette et al., 2009). The stillbirth rates for singleton births born to heifers inseminated with sexed and conventional semen were both higher than the reported stillbirth rate of $8.3 \%$ for conventional semen in some studies (Mangurkar et al., 1984). An increased stillbirth rate for both sexes (especially males) was found when sexed semen was compared with conventional semen by Norman et al., (2010).

In conclusion the sex sorted semen with a realized conception rate of 39.9 per cent, which is comparable to the performance of unsexed conventional frozen semen, and a female to male ratio of 91:9, showed very promising results under majority Indian small holder farm conditions, These findings comes as a boon to the farmers to adopt and use sex sorted semen that would provide an additional economic returns, and will help to overcome the limitations such as reducing the burden of male animal maintenance under the situation of agriculture mechanization, fodder and feed deficits. The State Animal Husbandry Departments should encourage the farmers on the use of sex sorted semen to produce dairy heifers needed for enhancing the dairy production both at farm and state level through provision of financial incentives and support systems.

\section{Acknowledgement}

We acknowledge the contributions of Dr. Jayant Khadse, Dr. Shivaji Sontakke and all state field team for their valuable help. Support and guidance of Mr Girish Sohani (President BAIF) and Dr Ashok Pande (Group Vice President BAIF) is also greatly acknowledged.

\section{References}

BAIF Development Research Foundation. 2020. http://www.baif.org.in/.

Cerchiaro I., M. Cassandro, R. Dal Zotto, P. Carnier, and L. Gallo1A Field Study on Fertility and Purity of Sex-Sorted Cattle Sperm J. Dairy Sci. 90:2538-2542

Conception rate and sex ratio under field conditions. J. Entomol. Zool. Studies, 6(1): 702-705.

De Vries A, Overton M, Fetrow J, Leslie K, Eicker S, Rogers G. Exploring the impact of sex semen on the structure of the dairy industry. J Dairy Sci. 2008; 91:847-856. 
DeJarnette J. M., R. L. Nebel, C. E. Marshall,J. F. Moreno, C. R. McCleary, and R. W. Lenz Effect of Sex-Sorted Sperm Dosage on Conception Rates in Holstein Heifers and Lactating Cows.J. Dairy Sci. 91:1778-1785 doi:10.3168/jds.2007-0964

doi:10.3168/jds.2006-694

Dyke G V and Patterson H D. 1952. Analysis of factorial arrangements when the data are proportional. Biometrics 8:1-12.

Fonseca, F. A., J. H. Britt, B. T. McDaniel, J. C. Wilk, and A. H. Rakes. 1983. Reproductive traits of Holsteins and Jerseys. Effects of age, milk yield, and clinical abnormalities on involution of cervix and uterus, ovulation, estrous cycles, detection of estrus, conception rate, and clays open. J. Dairy Sci. 66:1128.

GoI, 2019. DAHD Annual report 2019-20.

Available at, https://dahd.nic.in/annual_report.

González-Marín, C., Góngora, C.E., Gilligan, T.B., Evans, K.M., Moreno, J.F. and Vishwanath, R., 2018. In vitro sperm quality and DNA integrity of SexULTRA ${ }^{\text {TM }}$ sex-sorted sperm compared to non-sorted bovine sperm. Theriogenology, 114, pp.40-45.

Gwazdauskas, F. C., J. A. Lineweaver, and W. E. Vinson. 1981. Rates of conception by artificial insemination of dairy cattle. J. Dairy Sci. 64:358.

Healy, J. K. House, and P. C. Thomson Artificial insemination field data on the use of sexed and conventional semen in nulliparous Holstein heifers J. Dairy Sci. 96:1905-1914

Hohenboken WD. 1999. Application of sex semen in cattle production. Theriogenology, 52:1421-1433

Hosmer D W and Lemeshow S. 1989. Applied Logistic Regression. John Willey and Sons, New York. http://dx.doi.org/ 10.3168/jds.2012-5465
Ljupche Kochoski, Zoran Filopov, IlchoJoshevski, StevcheIlievski, Filip Davkov 2014 First Results From Insemination With Sex-Sorted Semen In Dairy Heifers In Macedonia http://dx.doi.org/10.14432/j.macvetrev. 2014.10.025

Mangurkar, B. R., J. F. Hayes, and J. E. Moxley. 1984. Effects of calving easecalf survival on production and reproduction in Holsteins. J. Dairy Sci. 67:1496-1509.

Mocé E, Graham JK, Schenk JL. 2006. Effect of sexsorting on the ability of fresh and cryopreserved bull sperm to undergo an acrosome reaction. Theriogenology, 66:929-936.

Niemann H, Kuhla B, Flachowsky G (2011). Perspectives for feed efficient animal production. J. Anim. Sci. 89: 43444363.

Nishant Sharma, DK Chand, ShriyaRawat, Mridula Sharma and Harshit Verma. Effect of sexed semen on conception rate and sex ratio under field conditions. Journal of Entomology and Zoology Studies 2018; 6(1): 702-705

Norman, H.D., Hutchison, J.L. and Miller, R.H. (2010). Use of sexed semen and its effect on conception rate, calf sex, dystocia, and stillbirth of Holsteins in the United States. J. Dairy Sci., 93: 3880-3890.R Core Team, 2020. R: A language and environment for statistical computing. R Foundation for Statistical Computing, Vienna, Austria. Version: 4.0.2.). https://www.R-project.org/

Patel S.B. and Jethva P.C. 2019 Use of Sexed Semen in Indian Dairy Cattle: A Case Study Amul Research and Development Association (ARDA) Amul Dairy, Anand-388001 (Gujarat) the Indian Journal of Veterinary Sciences \& Biotechnology (2019) Volume 14, Issue 3, 54-57.

Ron M, Bar-Anan R and Wiggans G R. 1984. 
Factors affecting conception rates of Israeli Holstein cattle. Journal of Dairy Science 67: 854-860.

Seidel GE Jr, Schenk JL, 2002. Field trials with sexed, frozen bovine semen. 19th TechnolConfArtif Insemination Reprod, NatlAssocAnim Breeders, Columbia, MO, USA.pp: 64-69.

Seidel, G. E. Jr. 2007. Overview of sexing sperm. Theriogenology 68:443-446.

Sharma, N., Chand, D.K., Rawat, S., Sharma, M. and Verma, H. (2018). Effect of sexed semen on
Tubman, L. M., Z. Brink, T. K. Suh, and G. E. Seidel Jr. 2004. Characteristics of calves produced with sperm sexed by flow cytometry/ cell sorting. J. Anim. Sci. 82:1029-1036.

Valerie J. Grant and Lawrence W. Chamley.Sex-Sorted Sperm and Fertility: An Alternative View, BIOLOGY OF REPRODUCTION 76, 184-188 (2007).

Weigel KA, 2004. Exploring the role of sex semen in dairy production systems. J Dairy Sci, 87: 120-130.

\section{How to cite this article:}

Sachin Joshi, Kaustubh Bhave, Vinod Potdar, Yuvraj Gaundare, Nikhil Punde, Tejashree Shirsath and Marimuthu Swaminathan. 2021. Performance of sex sorted semen under Indian Small Holder Dairy Farming Systems. Int.J.Curr.Microbiol.App.Sci. 10(02): 1335-1343. doi: https://doi.org/10.20546/ijcmas.2021.1002.158 